\title{
Bankaların Piyasa Değeri ile Ekonomik Katma Değeri Arasındaki Nedensellik İlişkisi: Panel Nedensellik Analizi
}

Tuğba Figankaplan*

\section{Öz}

Bu çalışmanın amacı, bankaların piyasa değeri ile ekonomik katma değeri arasındaki nedensellik ilişkisini analiz etmektir. Bu amaçla Türkiye'de halka açık 7 mevduat bankasının 2004-2018 yıllarına ait çeyrek dönem verileri kullanılarak, piyasa değerleri ile ekonomik katma değerleri arasındaki nedensellik ilişkisi panel eşbütünleşme ve nedensellik analizi yapılarak incelenmiştir. Panel eşbütünleşme testi sonucunda değişkenler arasında uzun dönemli eşbütünleşme ilişkisi olduğu anlaşılmıştır. Dumitrescu ve Hurlin (2012) panel Granger nedensellik analizinde, panel seti için ekonomik katma değerden piyasa değerine doğru tek yönlü bir Granger nedensellik ilişkisi olduğu görülmüştür.

Anahtar Kelimeler: Ekonomik katma değer, Piyasa değeri, Panel eşbütünleşme testi, Dumitrescu ve Hurlin (2012) panel granger nedensellik analizi, Halka açık banka.

JEL Sınıflandırması: G12, G32, M21.

\section{Abstract - The Causality Relation Between Market Value and Economic Value Added of Banks: Panel Causality Analysis}

The purpose of this study is to investigate the causality relation between market value and economic value added of banks. For this purposes, the relationship between market value and economic value added of 7 publicly listed deposit banks in Turkey over the period of 2004-2018 has been examined by using panel cointegration and panel causality analysis. According to panel cointegration test it is obtained that there is long run cointegration among the variables. Dumitrescu and Hurlin (2012) panel Granger causality methods indicate uni-directional causality from economic value added to market value.

Keywords: Economic value added, Market value, Panel cointegration test, Dumitrescu and Hurlin (2012) panel granger causality analysis, Publicly listed bank.

JEL Classification: G12, G32, M21.

\footnotetext{
* İstanbul Ticaret Üniversitesi, Finans Enstitüsü, Doktora Programı - E-posta: figankaplan@gmail.com ORCID ID: https://orcid.org/0000-0002-5617-5550
} 


\section{Giriş}

Finansal piyasalarda artan işlem hacimleri, gelişen teknoloji ve entegrasyon, bankaları birbiriyle ve ekonominin bütünüyle oldukça bağımlı hale getirmiştir. Günümüzde bankalardan birinin veya birkaçının olumsuz etkileneceği bir durum, diğerleri ve hatta sistemin tamamı için riske dönüşebilmektedir. İlaveten küreselleşmenin bir sonucu olarak krizlerin ülkeler arasında yayılma olasılığı ve hızı da artmıştır. Bu bağlamda bankaların finansal performanslarının doğru şekilde ölçülmesi, finansal sorunlarının sistemin bütününe yayılmasının engellenmesine yönelik önlemlerin zamanında alınmasını ve çözüm maliyetlerinin azaltılmasını sağlayacaktır. Bu nedenle finansal performansın nesnel bir şekilde ölçülmesi ve izlenmesi son derece önemlidir.

Finansal performans, birden çok faktör tarafından belirlenen oldukça geniş kapsamlı bir niteliktir. Bu nedenle, tek bir göstergeye indirgenerek ölçülmesi güçtür. Bununla birlikte, bazı gösterge kümelerinden hareketle finansal performansın sayısallaştırılması mümkündür. Performans ölçütleri, bir yandan bankaların değer yaratan unsurlarını analiz ederken diğer yandan banka faaliyetlerinin finansal performans üzerindeki etkilerini ve bunun da bankanın karlılığında ve piyasa değerinde nasıl bir değişim yarattığını ortaya koymayı amaçlamaktadır. Bankaların ekonomideki işlevleri, faaliyetlerinin ve sundukları hizmetlerin niteliği, karşılaştıkları risklerin çeşitliliği, kamu gözetimine ve denetimine tabi olmaları gibi unsurlar, bankaların performans analizinin diğer firmalardan farklılık arz etmesine sebep olmaktadır. Bu bağlamda bankacılık sektöründe performans, finansal ölçütlerin yanı sıra finansal olmayan ölçütleri de içermektedir (Armitage, 1997).

Geleneksel finansal performans ölçüm yöntemleri, finansal tablolara yansıyan sonuçların kontrolüne ve değerlendirilmesine dayanmaktadır. Bu nedenle geçmiş performans ile ilgili bilgi sağlamanın ötesine geçememekte ve kısa dönemli sonuçlara odaklandığından, uzun vadeli stratejik kararların alınmasında gereksinim duyulan bilgileri sunmakta yetersiz kalmaktadır (Türker, 2005). Geleneksel yöntemlerin bankaların finansal performansını tüm boyutlarıyla ölçmekte yetersiz kalması, değişiklikleri eş zamanlı yansıtamaması, maddi olmayan varlıkların performans üzerindeki etkisini dikkate almaması, hisse fiyatlarıyla bağlantıyı tam olarak kuramaması gibi nedenler, yeni ölçüm yöntemlerinin geliştirilmesine yönelik arayışlara yol açmıştır (Akgül, 2004). Ayrıca küresel ekonomideki köklü değişim ve buna bağlı olarak finans kuramında ortaya çıkan gelişmeler, finansal yönetim anlayışının da değişmesine sebep olmaktadır. Bu değişim, en düşük maliyetle, en çok üretim ve yüksek kârı hedefleyen geleneksel yönetim anlayışından, günümüzün rekabetçi ortamı gereği olarak müşteri 
memnuniyeti, kalite ve yenilik gibi çok farklı ölçütlere ağırlık veren bir yönetim anlayışına geçiş olarak özetlenebilir. Özellikle 2008 küresel finans krizinin ardından finans sektöründe, finansal literatürde ve denetim otoritelerinin gündeminde, başta etik değerler olmak üzere "değer" kavramı daha fazla önem arz etmeye başlamıştır (Çetin, 2019). Buna bağlı olarak bankaların temel amacı, kâr maksimizasyonundan değer maksimizasyonuna kaymıştır (Strack ve Ulrich, 2002). Dolayısıyla finans literatüründe bu değişimi vurgulayan çalışmalar ağırlık kazanmıştır. Rasyo analizleri statik ve geçmişe dönük olduğundan günümüz bankacılığının ölçülmesi ve değerlendirilmesi açısından yeterli olmadığı, kalitatif öneriler getirebilecek dinamik ve geleceğe dönük analiz tekniklerin gerekli olduğu vurgulanmaya başlanmıştır (Gökbulut, 2009).

Bu bağlamda geleneksel finansal performans ölçüm yöntemlerinden farklı nitelikleri sebebiyle, ekonomik katma değer (economic value added, EVA) ve piyasa değeri yöntemleri ön plana çıkmıştır. Geleneksel yöntemlerde kar hesaplamasında sadece borçlanma maliyeti dikkate alınırken, EVA sermayenin maliyetini de dikkate almaktadır. Bu açıdan finansal performansın ölçülmesinde EVA, vergi sonrası net faaliyet karı ile bu karın elde edilebilmesi için kullanılan finansal yatırımın maliyetini birlikte hesaba katmaktadır (Brewer ve diğerleri, 1999). Piyasa değeri ise bir firmanın piyasada oluşan arz ve talebe göre belirlenen değeridir. Borsada işlem gören firmalar için piyasa değeri, aynı zamanda borsa değeri olmaktadır (Sipahi vd., 2011). Sözkonusu performans göstergelerine ilişkin olarak literatürde yapılan çalışmalar, bunların firmanın hisse değerini doğru yansıtma gücüne ve diğer performans göstergeleriyle mukayeseli karşılaştııımasına odaklanmaktadır.

Türkiye'de bankacılık sektörü 1990'lı yıllardaki yüksek enflasyon ortamında kamu kesimini yüksek reel faiz karşılığı finanse ederek oldukça yüksek kârlılık seviyelerine ulaşmıştır. Ancak bu kârlılık seviyelerinin, bankaların operasyonel etkinliklerinin ve finansal performanslarının da yüksek olduğu anlamına gelmediği, 2001 yılında yaşanılan bankacılık krizi ile anlaşılmıştır. Özellikle 2001 krizinden sonraki yıllarda düşük enflasyonlu bir ortamda kamu kesiminin finansmanı yerine gerçek bankacılık faaliyetleri ile kâr etme zorunluluğunun doğması, bir taraftan müşteri memnuniyeti, hizmet kalitesi gibi mali olmayan performans göstergelerini ön plana çıkarmış, diğer taraftan bankaları maliyet yönetimi ve operasyonel etkinlik gibi alanlara odaklanmaya yöneltmiştir. Bankacılık sektörüne yabancı bankaların girişleri ile hem rekabet artmış hem de yabancı bankalar kendi yönetim uygulamalarını Türkiye'ye taşımıştır. Yabancı bankaların faaliyetlerini yurtdışındaki ana bankalarına uyum sağlamak üzere düzenlemeleri, özelikle risk yönetimi ve kurumsal yönetim gibi alanlarda gelişmeleri de beraberinde getirmiştir. Yurtdışı ile oldukça eklemlenmiş, geliş̧miş bilgi sistemleri

T. Figankaplan, "Bankaların Piyasa Değeri ile Ekonomik Katma Değeri Arasındaki Nedensellik ilişkisi: Panel Nedensellik Analizi", BDDK Bankacilık ve Finansal Piyasalar Dergisi, 14, (1), 2020, 39-67 
altyapısını haiz bankacılık sektöründe, bu gelişmelerin performans ölçümü ve yönetimi uygulamalarını ne ölçüde ve ne şekilde etkilediği başıı başına ilgi çekici bir konudur. Ayrıca 2001 krizinin ardından bankacilık sektöründe yaşanan yapısal değişimin, ne ölçüde "değer" yaratan bir değişim olduğu da incelenmeye değer bir husustur.

Bir bankanın hissedarları, yatııımcıları ve diğer tüm paydaşları açısından en önemli hususlardan biri, bankanın finansal performansının göstergesi olarak yararlanılan ölçütlerin bankanın gerçek değerini yansıtmasıdır. Ancak bu şekilde bankanın performansını doğru değerlendirerek isabetli yatııı kararları vermeleri mümkün olabilir. Hangi performans göstergesinin hisse değerini doğru yansıttığı, literatürde sıklıkla tartışılan bir konudur. Piyasa değeri ve ekonomik katma değer hem literatürde incelenen hem de uygulamada başvurulan yöntemler olmasına rağmen, bu iki gösterge arasındaki nedenselliğin yönü konusunda henüz bir ampirik uzlaşıya varılamamıştır. Bu konu, önemli politika çıkarımlarına sahip olması nedeniyle bu çalışmada inceleme konusu olarak seçilmiştir. Bu çalışma ile finansal performans ölçümüne ilişkin iki yöntem olan piyasa değeri ile ekonomik katma değerin karşılaştırmalı olarak değerlendirildiği kavramsal ve uygulamalı bir çerçeve sunulması amaçlanmaktadır. Böylelikle sektörel aktörlerin ve karar vericilerin performans ölçüm yöntemlerini gözden geçirerek daha modern, değişen intiyaçlara daha uygun, daha etkin sistemler tasarlamasına katkı sağlanması hedeflenmektedir.

Bu çalışmanın ikinci bölümünde konu ile ilgili literatüre değinilecektir. Çalışmanın üçüncü bölümünde, ekonomik katma değer (EVA) kavramı açıklanacaktır. Ayrıca EVA yöntemiyle performans analizi konusuna yer verilecektir. Çalışmanın dördüncü bölümünde, bankaların ürettikleri EVA ile piyasa değerleri arasındaki ilişki ekonometrik açıdan analiz edilecektir. Bu bağlamda, Borsa İstanbul'da (BIST) 01.01.200431.12.2018 döneminde işlem gören 7 mevduat bankasının çeyrek dönem verileri kullanılarak ürettikleri EVA ile piyasa değeri arasındaki ilişki panel eşbütünleşme ve panel nedensellik yöntemleri kullanılarak incelenecektir. Bu suretle, çalışmanın üçüncü bölümünde değinilen EVA yöntemi sayısallaştırılarak, uygulamalı şekilde analiz edilecektir. Çalışma, genel bir değerlendirmenin yapıldığı sonuç bölümüyle sona ermektedir.

\section{Literatür Özeti}

Bu çalışmada araştırma konusunun sınırlarının belirlenmesi ve konunun somutlaştııııması, bulgu ve sonuçların önceki çalısmalarla ilişkilendirilerek değerlendirilmesi amacıyla aşağıda özetlenen literatür taraması yapılmıştır. 
Prakash vd. (2003), bir firmada EVA yönteminin uygulanmasından sonra, firmanın likidite, varlık kalitesi, kârlılık ve piyasa değeri gibi önemli unsurlarına ilişkin rasyolarında bir iyileşme olup olmadığını incelemiştir. Bu alanlara ilişkin 10 rasyo çalışma kapsamına alınmıştır. Bunlar, likiditeye ilişkin olarak cari oran ve asit test oranı, varlık kalitesine ilişkin olarak stok devir hızı, sabit kıymet devir hızı ve toplam aktifler devir hızı, kârııı̆a ilişkin olarak satışların kâr marjı, kâr etme gücü rasyosu, aktif kârlılığı, özkaynak kârlılığı, piyasa değerine ilişkin olarak da fiyat/kazanç oranıdır. Çalışma kapsamında 47 firmanın EVA uygulamadan önceki ve uyguladıktan sonraki rasyoları, non-parametrik Wilcoxon Rank-Sum yöntemiyle test edilmiştir. Her bir rasyo bazında yapılan sözkonusu test neticesinde, toplam aktifler devir hızı ve kâr marjı rasyoları dışındaki 8 rasyonun, EVA kullanımından sonra iyileşme sergilediği tespit edilmiştir. Özellikle firmalar açısından büyük önem arz eden kâr etme gücü rasyosu, aktif kârlıı̆ı, fiyat/kazanç oranı ve özkaynak kârlıığı rasyolarındaki iyileşme bakımından EVA'nın etkili olduğu ifade edilmiştir.

Worthington ve West (2004), Avusturalya'da faaliyet gösteren 110 firmanın, 1992-1998 dönemine ilişkin verilerini kullanarak, EVA'nın hisse getirileriyle, yaygın olarak kullanılan muhasebe bazlı diğer ölçüm yöntemlerinden daha fazla ilişkili olup olmadığını analiz etmiştir. Bu kapsamda kullanılan muhasebe bazlı göstergeler gelir, net nakit akımları ve kalan gelirdir. Sabit etkiler yöntemiyle yapılan panel veri regresyon analizi sonucunda, hisse getirilerinin, diğer değişkenlere kıyasla, EVA ile daha fazla ilişkili olduğu tespit edilmiştir.

Kim (2006), EVA'nın firma değeriyle, diğer geleneksel performans göstergelerinden daha fazla ilişkili olup olmadığını araştırdığı çalışmasında, hisseleri borsada işlem gören 23 konaklama firmasının 1995-2001 yıllarına ait verilerini kullanmıştır. Sözkonusu firmaların gelirler, nakit akımları ve EVA ile piyasa değerleri arasındaki ilişki, regresyon analizi ile ölçümlenmiştir. Analiz neticesinde, firmaların piyasa değerini açıklamada gelirlerin daha fazla faydalı olduğu, EVA'nın ise açıklama gücünün bunlardan daha düşük olduğu görülmüştür. Bu nedenle EVA'nın sözkonusu muhasebe bazlı ölçüm yöntemlerinden belirgin bir üstünlüğünün tespit edilemediği ifade edilmiştir.

Kyriazis ve Anastassis (2007), EVA'nın hisse getirilerindeki değişimi açıklama gücünü, net gelir, faaliyet geliri ve kalan gelir (residual income) göstergeleriyle karşılaştırmalı olarak analiz etmiştir. Bu amaçla, hisseleri Atina Borsasında işlem gören 107 finansal olmayan firmanın 1996-2003 dönemini kapsayan 8 yıla ilişkin verileri kullanılarak regresyon analizi yapılmıştır. Çalışmada, net gelir ve faaliyet geliri değişkenlerinin hisse getirilerindeki değişimleri açıklamada EVA'ya kıyasla daha fazla belirleyici

T. Figankaplan, “Bankaların Piyasa Değeri ile Ekonomik Katma Değeri Arasındaki Nedensellik Illişkisi: Panel Nedensellik Analizi”, BDDK Bankacilık ve Finansal Piyasalar Dergisi, 14, (1), 2020, 39-67 
olduğu sonucuna ulaşılmıştır. Ayrıca, EVA'nın firmaların piyasa katma değeriyle olan ilişkisinin diğer değişkenlerden daha fazla olduğuna dair bir bulgu tespit edilemediği de ifade edilmiştir. Bu bağlamda EVA'nın, faydalı bir performans değerlendirme araCı olmakla birlikte, hissedar değeriyle diğer muhasebesel değişkenlerden daha fazla ilişkili olmadığına dikkat çekilmiştir.

Vijayakumar (2011), Hindistan'da otomotiv sektöründe faaliyet gösteren 20 firmanın 1996-1997'den 2008-2009'a kadar olan döneme ilişkin verilerini kullanarak, EVA'nın iyi bir performans göstergesi olup olmadığını araştırmıştır. Bu amaçla, firmaların satış ciroları, satışların getirisi (ROS), toplam varlık getirisi (ROTA), kullanılan sermayenin getirisi (ROCE), hisse başına kazanç (EPS), piyasa değeri (MV) ve piyasa katma değerinden (MVA) oluşan finansal göstergeler ile EVA arasındaki ilişki faktör analizi yöntemiyle incelenmiştir. Bu analizde, hangi faktörlerin hissedar kazancını artırmada en fazla etkili olduğunun araştıııması amaçlanmıştır. Faktör analizi sonucunda, sözkonusu 8 finansal değişkenden 3 tanesinin, toplam değişimin \%69,9'unu açıklayacak kadar etkin olduğu belirlenmiştir. Ayrıca satışlar ve vergi sonrası kâr değişkeninin EVA ile güçlü ilişkisi olduğu tespit edilmiştir.

Kootanaee vd. (2012), şirketlerin performansını en iyi ölçen yöntemi belirlemek amacıyla, Tahran Borsasında işlem gören 117 firmanın, 2005-2009 yılları arasında piyasa değeri ile EVA, faaliyet nakit akımları (OCF) ve hisse başına kazanç (EPS) değerleri arasındaki ilişkiyi incelemiştir. Geleneksel ölçüm yöntemi olarak faaliyet nakit akımları ile hisse başına kazanç göstergelerinin seçilmesinin sebebi, bunların özellikle kârlılık ve likiditeyle olan bağlantısı olduğu ifade edilmiştir. Bağımsız değişkenler olan EVA, EPS ve faaliyet nakit akımlarının, bağımlı değişken olan piyasa değerine olan etkisi, panel veri regresyon analizi ile incelenmiştir. Sonuç olarak, EVA ve EPS'nin piyasa değeri üzerinde önemli etkisi olduğu tespit edilmiştir. Ayrıca piyasa değeri üzerindeki etkisi bakımından, EVA'nın EPS'den daha etkili bir değişken olduğu belirtilmiştir.

Bhasin ve Shaikh (2013), Hindistan'da faaliyet gösteren 5 şirketin 2007-2011 yıllarını kapsayan çalışmasında, şirketlerin değer yaratma stratejilerini incelemiştir. Sözkonusu çalışmada, EVA ile geleneksel performans göstergeleri olan hisse başına getiri (EPS), net varlık getirisi (NONW) ve kullanılan sermayenin getirisi (ROCE) kullanılarak trend analizi ve regresyon analizi yapılmış ve bunların şirketlerin piyasa değeri üzerindeki etkisi incelenmiştir. Çalışmada sonuç olarak, EVA'nın hem yaratılan değerin hem de performansın bir ölçütü olduğu, ancak şirket değeriyle ilişkisinde diğer geleneksel ölçüm yöntemlerine kıyasla belirgin bir üstünlüğünün tespit edilemediği ifade edilmiştir. 
Panigrahi (2014), hisse değerini azamileştirmede ekonomik katma değerin önemini araştırmıştır. Malezya'da faaliyet gösteren ve hisseleri borsada işlem gören 28 inşaat sektörü firmasının 2003-2012 yılları arasındaki 10 yıllık verileri kullanılarak, sabit etkiler yöntemiyle yapılan panel veri regresyon analizi neticesinde, EVA ile hisse değeri arasında pozitif ve güçlü bir ilişki tespit edilmiştir. Çalışma kapsamında, geleneksel performans ölçümü yöntemleri olan yatırımların getirisi (ROI), özkaynak getirisi (ROE), hisse başına getiri (EPS), net varlık getirisi (RONW) ve kullanılan sermayenin getirisi (ROCE) ile modern ölçüm yöntemi olan EVA'nın bağımsız değişken olarak alındığı panel veri regresyon analizinde bunların, bağımlı değişken olan hisse değeri ile ilişkisi incelenmiştir. Sonuç olarak, sözkonusu geleneksel ölçüm yöntemleriyle karşılaştırıldığında, EVA'nın hisse değeri üzerinde daha kesin sonuç verdiği ifade edilmiştir. Firma ne kadar çok EVA yaratırsa, hisse değerindeki artışın o kadar çok olacağı ifade edilmiştir. Bu nedenle firmaların hisse değerinin analizinde EVA'ya daha fazla odaklanılması gerektiği belirtilmiştir. Geleneksel yöntemlerden ise EPS'nin analizinin EVA ile karşılaştırmalı yapılmasının faydalı olacağı vurgulanmıştır.

Fayed ve Dubey (2016), Birleşik Arap Emirlikleri'nde faaliyet gösteren ve borsada işlem gören 43 firmanın 2008-2013 yılları arasındaki yıllık verilerini kullanarak bir panel veri regresyon analizi yapmıştır. Bu çalışmada performans ölçüm yöntemleri 3 gruba ayrılmış ve bunların hissedar getirilerine etkisi karşılaştırmalı olarak analiz edilmiştir. Birinci grup olan geleneksel muhasebe bazlı performans ölçüm yöntemi grubunda 11 değişken yer almaktadır. Bunlar, net defter değeri / toplam varlıklar rasyosu, satışların getirisi rasyosu (toplam satışlar / satış gelirleri), net defter değeri, hisse başına net defter değeri, ortalama toplam varlıkların getirisi, ortalama net özkaynakların getirisi, net kâr, faaliyet kârı, serbest nakit akımı marjı (serbest nakit akımları / gelirler), serbest nakit akımları ve hisse başına getiri rasyosudur. ikinci grubu, piyasa bazlı performans ölçüm yöntemi olarak alınan fiyat / kazanç rasyosu, piyasa fiyatı / defter değeri rasyosu ve fiyat / gelirler rasyosundan oluşan 3 değişken teşkil etmektedir. Üçüncü grupta ise değer bazlı performans ölçüm yöntemleri olan 4 değişken yer almaktadır. Bunlar kalan gelir (residual income), EVA, EVA marjı (EVA / gelirler) ve EVA momentumu (EVA'daki yıllık değişim / önceki dönem satışları) değişkenleridir. Bağımlı değişkenin toplam hissedar getirisi (total shareholders value) olduğu panel veri regresyon analizinde, bağımsız değişkenler sözkonusu 3 grupta yer alan performans ölçüm verileridir. Toplam 18 bağımsız değişkenden oluşan regresyon analizi, en uygun analiz yöntemini tespit etmek amacıyla, başlangıçta 5 farklı panel veri regresyon yaklaşımı uygulanarak analiz edilmiştir. Bunlar, sabit etkiler (fixed effect), rastsal etkiler (random effect), OLS ortak etki-

T. Figankaplan, “Bankaların Piyasa Değeri ile Ekonomik Katma Değeri Arasındaki Nedensellik Illişkisi: Panel Nedensellik Analizi”, BDDK Bankacilık ve Finansal Piyasalar Dergisi, 14, (1), 2020, 39-67 
ler (OLS common effect), Driscall-Kraay ve Prais-Winsten regresyon modelleridir. Modelde belirleyicilik gücü en yüksek olan değişkenleri saptamak amacıyla yapılan ekonometrik eleme işlemlerinin ardından bağımsız değişken sayısı 8'e düşmüştür. Bunlar, net defter değeri/toplam varlıklar rasyosu, satışların getirisi rasyosu, faaliyet kârı, serbest nakit akımları marjı, piyasa fiyatı/defter değeri rasyosu, kalan gelir, EVA marjı ve EVA momentumdur. Bu değişkenler ile yapılan analiz sonucunda, toplam hissedar değerindeki değişimi açıklama gücü en yüksek olan değişkenin, değer bazlı performans ölçüm yöntemleri grubu değerlendirildiğinde EVA momentum olduğu, 3 grup birlikte değerlendirildiğinde ise piyasa fiyatı/defter değeri rasyosu olduğu sonucuna ulaşılmıştır.

Kijewska (2016) çalışmasında, EVA'da değişime neden olan faktörleri ve bunlar arasındaki nedenselliğin yönünü incelemiştir. Çalışma kapsamında Polonya'da maden sektöründe faaliyet gösteren halka açık bir firmanın 2012-2014 arasındaki verileri kullanılarak, vergi öncesi net faaliyet karı, yatırılan sermayenin devir hızı, ortalama ağırlıklı sermaye maliyeti ve yatırılan sermaye olmak üzere dört unsurun EVA üzerindeki etkisi araştırılmıştır. Sonuç olarak sözkonusu unsurların EVA üzerindeki etkisinin yıldan yıla değiştiği ifade edilmiştir. Buna göre, 2012 ve 2013 yıllarında vergi öncesi net faaliyet karı ve yatırılan sermayenin devir hızı ile EVA arasında ters yönlü bir ilişki olduğu, ancak 2014 yılında bunun tersinin gerçekleştiği belirtilmiştir. Ağırlıklı ortalama sermaye maliyeti ve yatırılan sermaye ile EVA arasında tüm yıllarda ters yönlü bir ilişki tespit edilmiştir. Illişkinin yönünün ise sözkonusu faktörlerden EVA'ya doğru olduğu ifade edilmiştir. Çalışmada, EVA'yı etkileyen faktörlerin firmadan firmaya değişiklik göstereceği, hatta aynı firma için yıldan yıla farklılaşabileceği, bu nedenle EVA'nın avantajları konusunda genellemeler yapmaktan kaçınarak, her firma bazında değerlendirme yapılması gerektiği sonucuna ulaşılmıştır.

Wadi ve Saqfalhait (2016), Ürdün ticari bankalarını analiz ettiği çalışmalarında, geleneksel değerlendirme ölçütü olan özkaynak kârlılığını (ROE) ve modern değerlendirme ölçütü olan ekonomik katma değeri (EVA), bankaların piyasa katma değerine etkileri bakımından incelemiştir. Çalışmada, bankaların 2000-2013 dönemine ilişkin verilerini kapsayan panel veri analizi gerçekleştirilmiştir. Sonuç olarak hem EVA'nın hem de ROE'nin Ürdün bankacılık sektöründe sözkonusu dönemde üretilen piyasa katma değerine istatistiksel olarak önemli düzeyde pozitif etkisinin olduğu, ancak EVA'nın etkisinin daha fazla olduğu tespit edilmiştir.

Bognarova (2017) çalışmasında, performans göstergeleri olan EVA, hisse başına getiri (EPS) ile piyasa katma değeri (MVA) arasındaki ilişkiyi incelemiştir. EVA ve 
çalışma kapsamındaki geleneksel performans göstergesi olan EPS arasındaki başlıca farkın, EVA'nın hem borcun finansman maliyetini hem de özsermaye maliyetini dikkate alması ve muhasebesel bazı sapmaları minimize eden düzeltmeler içermesi olduğu belirtilmiştir. Çalışmada 50 Slovak firmanın 2010-2015 yılları arasındaki 6 yıla ilişkin verileri kullanılarak regresyon analizi yapılmıştır. Analiz sonucunda, piyasa katma değerindeki değişmeleri açılama gücü en yüksek olan bağımsız değişkenin EVA olduğu tespit edilmiştir. Dolayısıyla performans ölçüm yöntemi olarak EVA'nın diğer değişkene kıyasla, piyasa katma değerindeki değişimleri açıklama bakımından daha üstün olduğu vurgulanmıştır.

Panigrahi (2017), performans ölçüm yöntemleri ile hisse değeri arasındaki ilişkiyi incelediği çalışmasında, Malezya'da halka açık 43 inşaat firmasının 2003-2012 yıllarına ait verilerini kullanarak bir panel veri analizi yapmıştır. Çalışmada, değer bazlı performans kriterleri olan ekonomik katma değer, hisse başına getiri ve kâr dağıtım oranı ile hisse değeri arasında pozitif ve güçlü bir ilişki tespit edilmiştir. Firmaların gelirlerinin faaliyet giderlerinden fazla olması halinde ekonomik katma değer yarattıkları, bunun da hisse değerini artırıcı etkisinin olduğu ifade edilmiştir. Bu bağlamda hisse değerini artırmayı amaçlayan firmaların, ekonomik katma değeri artıracak politikalar uygulamalarının gerekli olduğu vurgulanmıştır.

Al-Awawdeh ve Al-Sakini (2018), Ürdün'de faaliyet gösteren ve hisseleri borsada işlem gören 13 ticari bankanın 2010-2016 döneminde, ekonomik katma değer, piyasa katma değeri ve geleneksel muhasebesel performans ölçüm yöntemlerinin bankaların hisse değerine etkisini analiz etmiştir. Çalışmada, bağımlı değişkenin hissedar değeri (shareholders' value), bağımsız değişkenlerin ise EVA, piyasa katma değeri (MVA), aktif kârlılığı (ROA), özkaynak kârlıığı (ROE) ve hisse başına getiri (EPS) olduğu bir regresyon analizi yapılmıştır. Analiz sonucunda sadece ROA ve EVA'nın hissedar değerini artırmakta pozitif ve istatistiksel olarak anlamlı bir etkisinin olduğu, diğer değişkenlerin önemli bir etkisinin tespit edilemediği belirtilmiştir. Çalışmada dikkate alınan geleneksel muhasebesel ölçüm yöntemleri olan ROE ve EPS'nin hisse performansının değerlendirilmesinde önemli araçlar olduğu belirtilmiştir. Bununla birlikte modern performans ölçüm yöntemlerinden biri olan EVA, yatırımcılar ve hissedarlar için doğrudan hisse fiyatlarıyla ilgili önemli bilgiler içerdiğinden, hisse değerini artıran bir rol oynadığı ifade edilmiştir. Dolayısıyla çalışmada, bankaların performans analizinde ROA ve EVA'nın kullanılması tavsiye edilmiştir. Ayrıca yatırımcıların ve finansal analistlerin de bu yöntemleri hisse değerleme modellerinde kullanmaları önerilmiştir.

T. Figankaplan, "Bankaların Piyasa Değeri ile Ekonomik Katma Değeri Arasındaki Nedensellik ilişkisi: Panel Nedensellik Analizi", BDDK Bankacilık ve Finansal Piyasalar Dergisi, 14, (1), 2020, 39-67 
Oboidot (2019) çalışmasında, 2016 yılında Amman Borsasında işlem gören finansal olmayan 71 firmanın piyasa katma değerindeki değişimleri açılama konusunda, EVA yönteminin, vergi sonrası net faaliyet kârı (NOPAT) ve net nakit akımları (NCF) yöntemine kıyasla üstün yönlerini araştırmayı amaçlamıştır. Amman Borsasında işlem gören finansal olmayan firmaların yaklaşık \%73'ünü teşkil eden 71 firma üzerinde yapılan çalışmada, bağımsız değişken olarak vergi sonrası net faaliyet kârı (NOPAT), net nakit akımları ve EVA alınmıştır. Bunların bağımlı değişken olan piyasa katma değerindeki değişim üzerindeki etkisi Univariate ve Multivariate regresyon analizi ile incelenmiştir. Univariate regresyon en etkili bağımsız değişkeni belirlemeyi, multivariate regresyon ise en iyi açılama gücüne sahip değişken setini belirlemeyi hedeflemektedir. Analiz sonucunda, tüm bağımsız değişkenlerin piyasa katma değeri ile pozitif ilişkili olduğu belirlenmiştir. Piyasa katma değerindeki değişimleri açıklamada en etkili değişkenin net nakit akımları olduğu tespit edilmiştir. Bunu sırasıyla EVA ve NOPAT takip etmektedir. En etkili açıklayıcı değişken setinin net nakit akımları ve EVA olduğu belirlenmiştir. NOPAT'ın ise herhangi bir açıklayıcı etkiye sahip olmadığı ifade edilmiştir. Sonuç olarak çalışmada, piyasa katma değerindeki değişimi açıklamada en güçlü yöntemin net nakit akımları olduğu tespit edilmiştir. Bunu EVA takip etmektedir. NOPAT ise net nakit akımlarına ve EVA'ya herhangi bir ilave açıklama gücü kazandırmamaktadır. Çalışma sonucunda, EVA'nın geleneksel muhasebesel ölçüm yöntemleri gibi bir performans ölçüm yöntemi olarak kullanılabileceği ifade edilmiştir. Doğru şekilde uygulanması halinde EVA'nın diğerlerinden daha gelişmiş bir ölçüm yöntemi olduğu ve yatırımcıların yatırım kararı verirken kullanmalarında fayda bulunduğu belirtilmiştir.

\section{Ekonomik Katma Değer (EVA)}

\subsection{Tanımı}

Ekonomik katma değer (EVA), en genel tanımla, bir firmanın faaliyet kârı ile bu faaliyet kârını yaratmak için kullandığı sermayenin maliyeti arasındaki farktır.

Bir firma, kullandığı sermayenin maliyetinden daha fazla kâr elde ettiği sürece, değer üretiyor demektir. Dolayısıyla değere dayalı bakış açısına göre firma yatırılan sermayeden, sermayenin alternatif maliyetinin üzerinde bir getiri elde etmedikçe kârlı değildir (Drucker, 1995). Eğer bir firma sermayenin maliyetinden daha fazla bir özkaynak getirisi elde edemiyorsa, firma ortakları hisseleri elde tutmaktan vazgeçerler ve böylece hisselerin fiyatı defter değerine iner. Ancak, bir firma özkaynak maliyetinden daha fazla gelir elde ediyorsa, hisse senetleri defter değerinin üzerine eklenecek bir primle satıı ve hissedarlar için değer yaratmış olur (Çelik, 2002). 
EVA yönteminde kârın tespitinde sermaye de fiyatlandırılır. Diğer bir ifadeyle firmanın sermayesi de maliyetlendirilerek kârın hesaplanmasında gider olarak dikkate alınır. EVA, sermaye maliyetini aşan kazanç olması yönüyle hissedarın servetindeki gerçek değişimi gösterir. Bu ise firmanın ekonomik kâr yaratma kapasitesinin bir ölçütüdür. Kullanılan toplam sermayenin maliyetine göre firma karının ne kadar fazla ya da az olduğunu gösterirken, temelde vergi sonrası faaliyet kârından firmaya yatırılan sermayenin maliyeti düşülerek hesaplanmaktadır (O'Byrne, 1996). Bu anlamda EVA, finansal performansın ölçülmesine yönelik muhasebe tabanlı bir yöntemdir. Ancak, EVA hesaplamalarında muhasebe verilerinin yanı sıra muhasebe raporlarında yer almayan veriler de kullanılmaktadır. Sözkonusu yöntem, kâr hesaplamasında sermayenin maliyetini de dikkate alarak finansal performansı, vergi sonrası net faaliyet kârı ile bu karın elde edilebilmesi için ihtiyaç duyulan varlıklara yapılan yatırım maliyetine bağlı olarak ölçmektedir (Brewer ve diğerleri, 1999).

EVA, finansal ve muhasebesel olarak 2 farklı şekilde hesaplanabilir (Çakıcı, 2008). Finansal olarak EVA, firmanın piyasa katma değeri (market value added, MVA) ile ilişkili olarak tanımlanır. Buna göre firmanın gelecekte beklenen EVA'larının bugüne indirgenen değeri, piyasa katma değerine eşittir.

Muhasebesel olarak ise EVA, "firmanın vergi sonrası net faaliyet kârı (Net Operating Profit After Taxes, NOPAT) ve özsermaye yükü arasındaki fark" olarak tanımlanabilir.

\section{EVA $=$ NOPAT - Özsermaye Yükü}

olarak gösterilebilir (Shil, 2009). Bu hesaplama sonucunda bulunan parasal tutarın pozitif olması, firmanın kâr elde etmek için yatırım yaptığı varlıkların maliyetinden daha fazla vergi sonrası faaliyet kârı elde ettiğine işaret etmektedir. Bu da katma değer yarattığı anlamına gelmektedir. Tutarın negatif olması ise, firmanın değer yaratmak yerine sermaye tükettiği anlamına gelmektedir. Firmanın finansal açıdan amacı, pozitif ve sürekli olarak yükselen bir EVA değerine sahip olmaktır. Bu bağlamda EVA, firmanın bir dönemde yarattığı "gerçek" değerin belirlenmesinde kullanılan bir ölçüttür. EVA ile firma hissedarlarının yatırdığı sermayenin karşılığında elde ettikleri değer hesaplanmaktadır.

EVA yöntemi, ekonomik kâr olarak adlandırılan kavrama dayanır. Ekonomik kâr, faaliyet kârından sermaye maliyetinin çıkarılması şeklinde tanımlanabilir (Aggarwal, 2001). Diğer bir ifadeyle ekonomik kar hesaplanırken, finansman giderleri olarak alınan borcun maliyetine ilaveten sermaye maliyeti de dikkate almaktadır. Dolayısıyla

T. Figankaplan, "Bankaların Piyasa Değeri ile Ekonomik Katma Değeri Arasındaki Nedensellik Ilişkisi: Panel Nedensellik Analizi”, BDDK Bankacilık ve Finansal Piyasalar Dergisi, 14, (1), 2020, 39-67 
EVA, düzeltilmiş vergi sonrası net faaliyet kârından hem borç hem de öz sermaye maliyetinin çıkartılması yoluyla hesaplanmaktadır.

\subsection{Ekonomik Katma Değeri (EVA) Hesaplama Adımları}

Bu çalışmada ekonomik katma değerin hesaplanması için, çalışma kapsamındaki 7 bankanın 2004-2018 dönemine ait çeyrek dönem verileri kullanılarak, her banka bazında ve her bir dönem itibariyle sırasıyla;

1. Vergi Sonrası Net Faaliyet Kârı (NOPAT)

2. Yatırılan Düzeltilmiş Özsermaye

3. Ağırlıklı Ortalama Özsermaye Maliyeti (WACC)

4. Özsermaye yükü

hesaplanmıştır. Ardından bu veriler kullanılarak her bankanın her bir dönem itibariyle ekonomik katma değerine ulaşılmıştır. Sözkonusu kalemlerin hesaplanması amacıyla yapılan işlemler aşağıda açıklanmıştır.

\subsubsection{Vergi Sonrası Net Faaliyet Kârının (NOPAT) Hesaplanması}

Bu çalışmada EVA hesaplamasında kullanılacak NOPAT tutarları, bankaların bağımsız denetimden geçmiş mali tabloları üzerinden Tablo 1'de (+/-) ile belirtilen ilave ve çıkartmalar yapılmak suretiyle, banka bazında ve her dönem itibariyle ayrı ayrı hesaplanmıştır (Köroğlu, 2008).

Tablo 1: Bankalarda NOPAT Hesaplaması

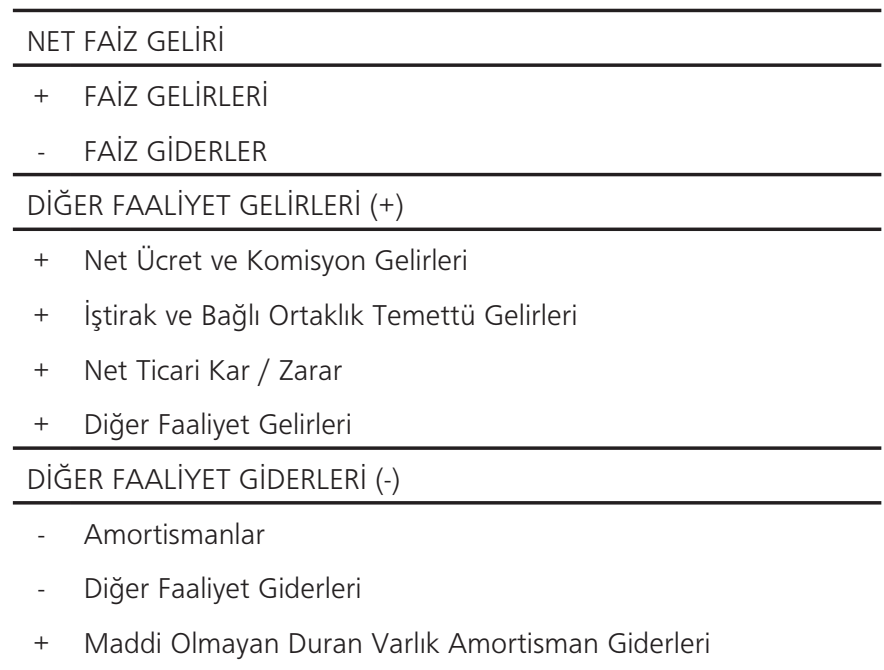

T. Figankaplan, "Bankaların Piyasa Değeri ile Ekonomik Katma Değeri Arasındaki Nedensellik ilişkisi: Panel Nedensellik Analizi”, BDDK Bankacılık ve Finansal Piyasalar Dergisi, 14, (1), 2020, 39-67 
+ Kredi ve Diğer Alacaklar Değer Düşüş Karşılığı

DÜZELTILMIŞ NAKIT FAALIYET VERGILERI (-)

I. Raporlanmış Gelir veya Kurumlar Vergisi (+)

II. Vergi Düzeltmeleri

A. Ertelenmiş Vergi Alacağı (+)

B. Ertelenmiş Vergi Borcu (-)

C. Olağanüstü Gelirlerin Vergisi (-)

D. Faiz Gelirlerinin Vergi Avantajı (+)

E. Olağanüstü Giderlerin Vergi Avantajı (+)

NOPAT

NOPAT hesaplamasında aşağıdaki hususlara dikkat edilmesi gerekmektedir.

- Amortisman giderleri, diğer faaliyet giderleri içinde raporlanması nedeniyle tekrar dikkate alınmamakta, ancak Maddi Olmayan Duran Varlık Amortisman Giderleri NOPAT'e ilave edilmektedir.

- Kredi ve Diğer Alacaklar Değer Düşüş Karşıı̆̆ı, diğer faaliyet giderleri kalemine ilave edilmektedir.

- Gelir tablosunda yer alan Ertelenmiş Vergi Karşılığı hesabı, bilançoda yer alan Ertelenmiş Vergi Aktifi ve Ertelenmiş Vergi Yükümlülüğü kalemlerinin netleştirilmesi sonucu elde edilir. Dolayısıyla Ertelenmiş Vergi Karşılığı negatif ise Ertelenmiş Vergi Yükümlülüğü (borcu), pozitif ise Ertelenmiş Vergi Aktifi (varlığı) olarak dikkate alınmıştır. Sonuç olarak Ertelenmiş Vergi Yükümlülüğü, ertelenmiş vergilerde artış olarak değerlendirilerek dönemin vergi tutarını gösteren Cari Vergi Karşılığı hesabından düşülmüş, Ertelenmiş Vergi Aktifi (varlığı) ise ertelenmiş vergilerde azalış olarak değerlendirilerek dönemin vergi tutarını gösteren Cari Vergi Karşılığı hesabına eklenmiştir.

- Olağanüstü Gelirlerin Vergisi, Düzeltilmiş Nakit Faaliyet Vergileri tutarından düşülmektedir. EVA, bankanın faaliyet gelirine dayalı bir ölçü olduğundan, süreklilik arz etmeyen, olağanüstü iş ve işlemlerden doğan gelirler sürekli faaliyet geliri niteliğinde değildir. Aynı şekilde, olağanüstü giderlerin vergi avantajı da Düzeltilmiş Nakit Faaliyet Vergilerine ilave edilmektedir.

Görüldüğü üzere NOPAT hesabında, firmanın sermaye yapısı ve borç/özsermaye dağılımı dikkate alınmamaktadır. Bu anlamda NOPAT, firmanın faaliyetlerinden nakit yaratma kapasitesinin bir ölçütü olup, faaliyet performansını ortaya koymakta, ancak

T. Figankaplan, "Bankaların Piyasa Değeri ile Ekonomik Katma Değeri Arasındaki Nedensellik Illişkisi: Panel Nedensellik Analizi”, BDDK Bankacilık ve Finansal Piyasalar Dergisi, 14, (1), 2020, 39-67 
sermaye yapısının getiri ve kar/zarar performansı üzerindeki etkisi hakkında bilgi vermemektedir. Diğer bir ifadeyle NOPAT, firmanın borç/özsermaye yapısından etkilenmemektedir. Bu nedenle NOPAT, EVA'nın hesaplanmasında düzeltilmiş özsermaye ile birlikte dikkate alınmaktadır.

\subsubsection{Yatırılan Düzeltilmiş Özsermayenin Hesaplanması}

Yatırılan düzeltilmiş özsermayenin hesaplanması amacıyla, Banka tarafından gerçekleştirilen ancak henüz kesinlik kazanmamış ve süreklilik arz etmeyen işlemlerin özsermaye üzerindeki etkilerinin ortadan kaldırılmasına yönelik olarak, bankalar tarafından yayınlanan dönem sonu özsermaye hesabına Tablo 2'de (+ / -) ile gösterilen ilave ve çıkarmalar yapılmıştır.

\section{Tablo 2: Bankalarda Özsermayenin Hesaplanması}

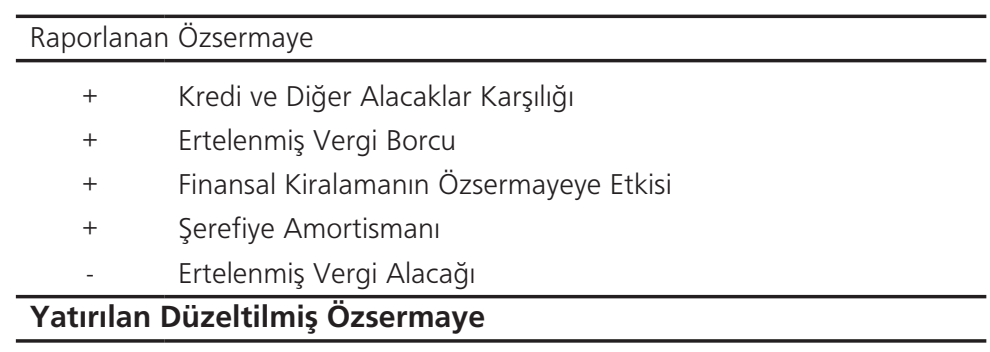

Yatırılan düzeltilmiş Özsermaye hesaplanırken,

- Kredi ve diğer alacaklar karşılığı (takipteki alacaklar provizyonu ve diğer provizyonlar) aslında nakit ödeme gerektirmeyen ama genel kabul görmüş muhasebe ilkeleri kapsamında tahakkuk ettirilen, birikmiş, nakit olmayan ve kesinleşmemiş yükleri temsil etmektedir. Bu nedenle, kredi ve diğer alacaklar karşılığı özsermayeye eklenmektedir.

- Bilançoda yer alan ertelenmiş vergi hesapları, kaydi vergi giderleri ile nakdi vergi yükleri arasındaki birikimli farkı ifade eder. Ertelenen vergi alacağı gelecekte ödenecek vergilerden indirilebilecek tutarı ifade etmektedir. Ertelenen vergi alacağının vergiden düşülmesi ya da özkaynaklar içerisinde yer alması özsermayenin olduğundan yüksek gözükmesine neden olacağından, ertelenen vergi alacağı özsermayeden çıkarılır. Aynı şekilde, ertelenmiş vergi borcu ise özsermayeye ilave edilmektedir.

- Finansal kiralama işlemleri, uluslararası muhasebe standartlarına göre muhasebeleştirilmemişse, kiralama konusu varlığının bugünkü değeri özsermayeye 
ilave edilirken amortisman gideri özsermayeden düşülmektedir.

- Gerek UMS'ye gerekse TFRS'ye göre şerefiye için amortisman ayrılması söz konusu değildir. Banka bilançolarında şerefiyenin bulunması halinde, standartlara göre muhasebeleştirilmesi durumunda hem NOPAT'ın hem de özsermayenin hesaplanmasında şerefiye ile ilgili herhangi bir düzeltme yapılmasına gerek yoktur. Ancak standartlar göz önünde bulundurulmadan şerefiyenin varlık olarak muhasebeleştirilmesi ve amortismana tabi tutulması durumunda, özsermaye üzerinde azaltıcı etki oluşturan şerefiye amortismanı özsermayeye ilave edilmektedir.

Belirtilen düzeltmeler, özsermayenin olduğundan düşük gözükmesine sebep olan kalemlerin EVA'nın hesabında dikkate alınan özsermayeye eklenmesini ve özsermayenin olduğundan fazla gözükmesine sebep olanların ise çıkarılmasını teminen yapılmaktadır.

\subsubsection{Ağırlıklı Ortalama Özsermaye Maliyetinin (WACC) Hesapla- ması}

Bankalarda Özsermaye maliyeti, Finansal Varlıkları Fiyatlama Modeli (CAPM), Gordon Büyüme Modeli ve Arbitraj Fiyatlama Modeli gibi yöntemlerle hesaplanabilir. Bu çalışmada, CAPM yöntemi kullanılmıştır. CAPM'in temel varsayımına göre, bankanın özsermayesinin maliyeti, yatırımcıların bankanın hisse senetlerini satın almak için istedikleri minimum getiri oranı, yani bekledikleri verim oranıdır. Bu getiri oranı, paranın zaman değeri ve risk primini içerir. Dolayısıyla sermayenin maliyeti, risksiz menkul kıymetlerin getirisine bu menkul kıymetlerin sistematik riski ile piyasa risk priminin çarpımının eklenmesiyle elde edilecek değere eşittir. Kısaca özsermayenin maliyeti, piyasa risk pirimi ile risksiz getiri oranının toplamından oluşmaktadır. Bankalarda EVA'nın hesaplanmasında, özsermaye maliyetinin tahmini CAPM modeli kullanılarak yapıldığında aşağıdaki gibi hesaplanabilir (Ceylan ve Korkmaz, 2008):

$k_{e b}=r_{f}+\beta\left(r_{m}-r_{f}\right)$

$k_{e b}$ : bankanın özsermaye maliyeti

$r_{f}$ : risksiz getiri oranı

$r_{m}$ : piyasanın beklenen getirisi

$\left(r_{m}-r_{f}\right)$ : piyasa risk pirimi

$\beta$ : bankanın hisse senetlerinin sistematik riski

T. Figankaplan, "Bankaların Piyasa Değeri ile Ekonomik Katma Değeri Arasındaki Nedensellik ilişkisi: Panel Nedensellik Analizi", BDDK Bankacilık ve Finansal Piyasalar Dergisi, 14, (1), 2020, 39-67 
Bu çalışmada bankaların özsermaye maliyetinin CAPM modeline göre hesaplamasında aşağıdaki yol izlenmiştir:

Risksiz getiri oranı olarak devlet tahvili veya hazine bonosunun faiz oranı kullanılabilir. Bu noktada, hazine bonosu veya devlet tahvilinin tarihi verilere dayanan faiz oranlarının ortalaması risksiz getiri oranı olarak kabul edilebilir. Bu çalışmada, risksiz getiri oranı olarak devlet iç borçlanma senetlerinin yıllık ortalama kümülatif bileşik faiz oranları kullanılmıştır. Hazine ve Maliye Bakanlığı'nın web sitesinde Hazine ve Maliye Bakanlığı Veri Dağıtım Sistemi'ndeki Merkezi Yönetim İç Borçlanma verilerindeki iç borçlanmanın ortalama maliyeti raporu kullanılarak kuponsuz ve sabit faizli DiBS'lerin 2004-2018 dönemi için dönem sonu (Mart-Haziran-Eylül-Aralık) yıllık kümülatif bileşik maliyetlerinin ortalaması alınarak ilgili dönemlere ait risksiz faiz oranları hesaplanmıştır.

Piyasa risk primi, tüm piyasa portföyündeki hisse senetlerinin geçmişteki ortalama getirileri ile risksiz menkul kıymetlerin geçmişteki ortalama getirileri arasındaki fark olarak hesaplanır. Piyasa risk primi, piyasanın (endeksin) getirisi ile hazine bonosunun tarihsel getirileri arasındaki farkların aritmetik ortalaması alınarak da hesaplanabilir. Diğer taraftan, bankaların gelirlerinin temelini, mevduat ile kredi arasındaki faiz oranı farkından (spread) kaynaklı faiz gelirinin oluşturduğu düşünülürse aslında bankalar için geçerli olacak risk priminin yani $\left(r_{m}-r_{f}\right)$ farkının, bankaların kullandırdıkları kredilere uyguladıkları faiz ile topladıkları mevduata uyguladıkları faiz arasındaki fark olduğu sonucuna ulaşılır. Çünkü bu spreadin içinde bankaların piyasadaki sistematik ve sistematik olmayan risklere ilişkin fiyatlamaları/değerlendirmeleri yani enflasyon risk primi, likidite risk primi, vade risk primi, geri ödememe risk primi ve operasyonel riskler ile maliyetler yer almaktadır. Bu noktadan hareketle çalışmada, Merkez Bankası istatistiklerinde bulunan bankaların haftalık ortalama TL mevduat faiz oranları ile ortalama bireysel ve ticari kredi faiz oranları esas alınarak, haftalık faiz oranlarının üç aylık ortalaması üzerinden dönemsel spread hesaplanmıştır.

Beta $(\beta)$ katsayısı, özsermaye maliyeti hesaplanacak olan bankanın hisse senetlerinin piyasa (pazar) portföyü karşısındaki duyarlığını gösterir. Beta, belirli bir zaman aralığında bankanın hisse senetlerinin kovaryansının tüm piyasa portföyünün varyansına oranı olarak tanımlanmaktadır. Bu çalışmada, bankaların beta katsayılarının hesaplanmasında, bankaya ait hisse senetlerinin borsadaki günlük kapanış fiyatları ile BiST 100 endeksinin günlük kapanış değerleri kullanılarak, hisse senedinin ve piyasanın günlük getirileri hesaplanmış ve bu veriler kullanılarak öncelikle ilgili bankaların dönemsel olarak hisse senetlerinin kovaryansı ve BIST 100 endeksinin varyan- 
sı hesaplanarak beta katsayısı belirlenmiştir. Gerek beta hesaplamalarında gerekse bankaların dönemsel piyasa değerinin hesaplanmasında hisse senetlerinin dönem sonu piyasa fiyatı esas alınmıştır.

\subsection{4. Özsermaye Yükünün Hesaplanması}

Özsermaye yükü genel olarak, yatırılan özsermaye ile özsermaye maliyetinin çarpımı şeklinde hesaplanabilir.

$$
\text { Özsermaye Yükü = Yatırılan Özsermaye * Özsermaye Maliyeti }
$$

Bu çalışmada, bankaların yatırılan düzeltilmiş özsermaye tutarları ilgili döneme ait özsermaye maliyetiyle çarpılmak suretiyle özsermaye yüküne ulaşılmıştır.

\subsubsection{Ekonomik Katma Değerin (EVA) Hesaplanması}

Bankaların yarattıkları EVA, bankanın faaliyetleri sonucu elde edilen ve hissedarlara dağıtılabilecek olan nakit akımlarından (NOPAT) özsermaye yükünün çıkarılması suretiyle bulunur. Bu bağlamda EVA, vergi sonrası net faaliyet karının (NOPAT) Özsermaye yükünü aşan kısmıdır.

$$
\begin{gathered}
\text { EVA }=\text { NOPAT }-(\text { Özsermaye Maliyeti * Yatırılan Özsermaye }) \\
\text { EVA }=\text { NOPAT }- \text { Özsermaye Yükü }
\end{gathered}
$$

Bu çalışmada, NOPAT ve özsermaye yükünün belirlenmesine ilişkin yukarıda açıklanan esaslar dikkate alınarak banka bazında ve her dönem itibariyle hesaplanan tutarlar kullanılmak suretiyle EVA hesaplaması yapılmıştır.

\subsubsection{Bankaların Piyasa Değerinin Hesaplanması}

Bu çalışmada bankaların piyasa değeri, dönem sonu piyasa değeri olarak alınmıştır. Piyasa değeri hesaplanırken, bankanın hesaplama tarihindeki hisse sayısı ile hesaplama tarihinde borsada işlem gördüğü fiyat esas alınmıştır.

Hesaplamalar sonucunda elde edilen EVA ve piyasa değeri kullanılarak oluşturulan model ve yapılan analiz aşağıda açıklanmıştır.

T. Figankaplan, "Bankaların Piyasa Değeri ile Ekonomik Katma Değeri Arasındaki Nedensellik Illişkisi: Panel Nedensellik Analizi”, BDDK Bankacilık ve Finansal Piyasalar Dergisi, 14, (1), 2020, 39-67 


\section{Yöntem ve Veri Seti}

\section{1. Çalışmanın Kapsamı, Veri Seti ve Değişkenler}

Bu çalışmada bankaların yarattıkları ekonomik katma değer ile piyasa değerleri arasındaki nedensellik ilişkisi analiz edilecektir. Piyasa değerinin tespiti için bankaların hisse senetlerinin değerinin piyasada oluşması yani borsada işlem görmesi gerekmektedir. Bu nedenle Türkiye'de faaliyette bulunan ve hisseleri borsada işlem gören halka açık mevduat bankaları çalışma kapsamına dahil edilmiştir. Çalışmada, sözkonusu bankaların 2004-2018 dönemini kapsayan 15 yıla ait çeyrek dönem verileri kullanılmıştır. Banka seçiminde uygulanan kriterler, 2004 yılından önce, en az bir tam yıl halka açık olması ve 2018 yılı sonuna kadar kesintisiz olarak halka açık olarak faaliyetine devam etmiş olmasıdır. Bu nedenle en geç 2002 yılı Aralık ayından itibaren halka açık olan ve bu nitelikleri sağlayan aşağıdaki 7 mevduat bankası çalışma kapsamına alınmıştır.

Tablo 3: Çalışma Kapsamındaki Bankalar

\begin{tabular}{lccc}
\hline Banka & $\begin{array}{c}\text { Borsada ilk işlem } \\
\text { Tarihi }\end{array}$ & Halka Açılık Oranı (\%) & $\begin{array}{c}\text { İşlem } \\
\text { Gördüğü } \\
\text { Pazar }\end{array}$ \\
\hline Akbank T.A.Ş. & 26.07 .1990 & 51,20 & Yıldız Pazar \\
\hline QNB Finansbank A.Ş. & 02.02 .1990 & 0,12 & Ana Pazar \\
\hline Şekerbank T.A.Ş. & 10.04 .1997 & 34,19 & Yına Pazar \\
\hline ICBC Turkey Bank A.Ş. & 23.05 .1990 & 10,23 & Yıldız Pazar \\
\hline Türkiye Garanti Bankası A.Ş. & 06.06 .1990 & 50,15 & Yıldız Pazar \\
\hline Türkiye İş Bankası A.Ş. & 03.04 .1989 & 32,02 & Yıldız Pazar \\
\hline Yapı Kredi Bankası A.Ş. & 08.01 .1988 & 18,10 & \\
\hline
\end{tabular}

Sözkonusu 7 bankanın 4 tanesi 2003 yılsonu itibariyle BiST 100 endeksine (eski adı ile IMKB Ulusal-100 endeksine) dahil bulunurken, bu bankaların BisT 100 endeksi içindeki ağılıkları aynı tarih itibariyle \%31 seviyesindedir. Öte yandan, 2003 yılı Aralık ayı itibariyle hisse senedi piyasasının toplam işlem hacminin \%30'una karşılık gelen işlem, sözkonusu 7 bankanın hisseleri aracılığıyla gerçekleşmiştir. Bankaların toplam işlem miktarı içindeki payları da \%27 olarak hesaplanmıştır. 30 Aralık 2003 
tarihi itibariyle, BisT'te işlem gören sözkonusu bankaların piyasa değeri, BisT'in toplam piyasa değerinin \%28'ini oluşturmaktadır. Bu veriler ışığında, seçilen bankaların halka açık finansal kurumları temsil kabiliyetinin yüksek olduğu düşünülmektedir. Diğer taraftan çalışma kapsamındaki 7 bankanın, bankacılık sektöründeki paylarına bakıldığında, 2003 yılsonu itibariyle sektördeki toplam payları \%48, sektörün toplam özkaynaklar büyüklüğündeki payları \%36 düzeyindedir. Aynı veriler 2018 yılsonu itibariyle sırasıyla \%44 ve \%38 olarak gerçekleşmiştir.

Çalışmada, EVA'nın hesaplanmasında kullanılan veriler ve piyasa değeri verileri, bankaların BiST'te yayınlanan bağımsız denetimden geçmiş mali tablolarından ve faaliyet raporlarından elde edilmiştir. Analiz edilen değişkenler olan ekonomik katma değer için EVA, piyasa değeri için PD sembolleri kullanılmıştır.

\subsection{Ampirik Bulgular}

Bu çalışmada bankaların ekonomik katma değeri ile piyasa değeri arasında nasıl bir ilişki olduğunu incelemek için veri bir zaman diliminde farklı bankaların karşılaştırılması gerekmektedir. Bu amaçla yatay kesit birimleri arasında karşılaştırma yapılması gerekir. Ancak piyasa değerinin ve ekonomik katma değerin yaratılması dinamik bir süreç olduğundan, bu analizde her bir yatay kesit biriminin zaman serisi verileri kullanılmalıdır. Dolayısıyla ampirik çalışmada hem yatay kesit hem de zaman boyutunu birlikte ele alan bir yönteme ihtiyaç vardır. Bu nedenle ekonomik katma değer ve piyasa değeri ilişkisinin değerlendirilebilmesi amacıyla panel veri analizi yapılacaktır. Panel veri analizi, sadece yatay kesit ya da sadece zaman serisi ile karşılaştırıldığında çeşitli avantajlara sahiptir. Panel veri modellerinde gözlem sayısı, kesit ve zaman serilerine kıyasla daha fazladır. Bu durumda elde edilecek parametre tahminleri daha güvenilir olacak ve tahmin edilen modeller daha az kısıtlayıcı varsayıma dayanacaktır. Ayrıca panel veri yönteminin kullanılması, kısa dönemli verilerle daha kapsamlı ve açıklayıcı bir ortak sonuca ulaşılmasını sağlayacaktır (Brooks, 2008).

Çalışmada değişkenler arası ilişkiler, panel veri eşbütünleşme ve nedensellik analizleriyle belirlenecektir. Sözkonusu analizler için Eviews 9.0, Gauss 10 ve Stata 12 programları kullanılmıştır.

Panel veri analizine başlamadan önce, verilerde sapan birimlerin olup olmadığı incelenmiştir. İstatistiksel anlamda sapan birimlerin, yani gözlem değerlerinin hepsinden ya da büyük bir kısmından uzak olan gözlemlerin bulunup bulunmadığı grafiksel olarak incelenmiştir. Bu kapsamda ortalamadan önemli ölçüde sapan veriye rastlanmamıştır. Çalışma kapsamında kullanılan verilerin tamamı bankacılık sektörüne ait

T. Figankaplan, “Bankaların Piyasa Değeri ile Ekonomik Katma Değeri Arasındaki Nedensellik Illişkisi: Panel Nedensellik Analizi”, BDDK Bankacilık ve Finansal Piyasalar Dergisi, 14, (1), 2020, 39-67 
olduğundan sektörel bir ayrım yapılmamış olup, oluşturulan veri seti dengeli bir veri setidir ve gözlemlenmeyen veri (missing data) sorunuyla karşılaşılmamıştır.

Panel veri durağanlık sınamalarında dikkate alınması gereken önemli bir konu, eğim katsayılarının heterojen olup olmadığı iken, diğer önemli konu serilerde yatay kesit bağımlılığının bulunup bulunmadığıdır. Serilerde eğim katsayılarının homojen veya heterojen olmaları durumunda birim kök ve eşbütünleşme testlerinin türü ve yorumları farklılaşabilmektedir. Aynı şekilde eğer serilerde yatay kesit bağımlılı̆ı söz konusu ise bu serilere durağanlık sınamalarının yapılması için ikinci kuşak testlerin uygulanması gerekmektedir.

Bu çalışmada eğim katsayılarının homojenlik sınaması Pesaran ve Yamagata (2008) tarafından geliş̧irilen delta testi yardımı ile yapılmıştır. Delta testine ilişkin hipotezler şu şekildedir:

$\mathrm{H}_{0}$ : Eğim katsayısı homojendir.

$H_{1}$ : Eğim katsayısı homojen değildir.

Eğer test istatistiklerinin olasılık değeri, \%5'den küçük ise $\mathrm{H}_{0}$ hipotezi reddedilmekte ve eğim katsayılarının heterojen olduğu kabul edilmektedir. Buna ilişkin yapılan homejenlik sınaması sonuçları, Tablo 4'de verilmiştir.

\section{Tablo 4: Homojenlik Testi}

\begin{tabular}{|lll|}
\hline & İstatistik & Olasılık \\
\hline Delta Tilde & $-0,640$ & 0,880 \\
\hline Delta Tilde Adj. & $-0,823$ & 0,704 \\
\hline
\end{tabular}

Tablo 4'e göre delta ve düzeltilmiş delta test istatistiklerinin olasılık değerleri \%5 anlamlılık düzeyinden büyük olduğu için eğim katsayılarının homojen olduğunu savunan sıfır hipotezi reddedilememektedir. Dolayısıyla homojenlik test sonuçlarına göre EVA ve PD değişkenlerine ait eğim katsayısının homojen olduğu anlaşılmaktadır.

Panel veri analizinde seriler arasındaki yatay kesit bağımlıı̆ının dikkate alınıp alınmaması, elde edilecek sonuçları önemli ölçüde etkilemektedir (Breusch ve Pagan, 1980; Pesaran, 2004). Bu nedenle analize başlamadan önce, serilerde ve eşbütünleşme denkleminde yatay kesit bağımlılığının varlığının test edilmesi ve yapılacak birim kök ve eşbütünleşme testleri seçilirken, bu durumun göz önünde bulundurulması gerekmektedir. Bu nedenle yatay kesit birimlerinin birbiriyle bağımlı olup olmadığı, seriye gelen bir şoktan aynı derece etkilenip etkilenmediği incelenmelidir. Yatay kesit 
bağımlıığının varlığı, panelin zaman boyutu yatay kesit boyutundan büyük olduğunda Breusch-Pagan (1980) Lagrange Multiplier (LM) testiyle; her ikisi de büyük olduğunda Pesaran (2004) Cross-Section Dependence (CD) testiyle araştırılabilmektedir. Bu çalışmanın kapsamına 15 yıla ait çeyrek dönem verileri ve 7 banka dahil olduğundan, paneli oluşturan yatay kesitler (bankalar) arasındaki bağımlılık, Breusch-Pagan (1980) tarafından bulunan ve Pesaran vd. (2008) tarafından sapması düzeltilen LMadj (Adjusted Lagrange Multiplier) testiyle incelenmiştir. Testin hipotezleri:

$H_{0}$ : Yatay kesit bağımlıı̆̆ yoktur.

$\mathrm{H}_{1}$ : Yatay kesit bağımlılığı vardır.

Test sonucunda elde edilecek olasılık değeri 0.05 ten küçük ise $H_{0}$ hipotezi \%5 anlamlılık düzeyinde reddedilmekte ve paneli oluşturan birimler arasında yatay kesit bağımlıı̆̆ının olduğuna karar verilmektedir (Pesaran vd., 2008).

\section{Tablo 5: Yatay Kesit Bağımlılığı Testi}

\begin{tabular}{|lcc|}
\hline Değişken & Test İstatistiği & Olasılık Değeri \\
\hline EVA & 1,542 & 0,026 \\
\hline PD & 1,654 & 0,035 \\
\hline Eşbütünleşme Denklemi & 26,242 & 0,000 \\
\hline
\end{tabular}

Tablo 5'den görüldüğü üzere, değişkenlere ait olasılık değerleri 0.05'ten küçük olduğundan, $\mathrm{H}_{0}$ hipotezi \%5 anlamlılık düzeyinde reddedilerek, seriler ve eşbütünleşme denklemi için yatay kesit bağımlılığının olduğu tespit edilmiştir. Seriler arasındaki yatay kesit bağımılı̆̆ı, analizde yer alan bankalardan birinin analiz kapsamındaki verilerini etkileyen bir şokun, diğer bankaların verilerini de etkileyeceğini ifade etmektedir. Yatay kesit bağımlılığı tespit edildiğinden, analizin devamında yatay kesit bağımlıığını dikkate alan ikinci nesil birim kök testleri ve panel eşbütünleşme yöntemleri uygulanmıştır. Bu bağlamda serilerin durağan olup olmadığı Im, Pesaran ve Shin (IPS) panel birim kök testiyle analiz edilecektir. IPS panel birim kök testinin hipotezleri şu şekildedir:

$\mathrm{H}_{0}$ : Seri durağan değildir.

$\mathrm{H}_{1}$ : Seri durağandır.

T. Figankaplan, "Bankaların Piyasa Değeri ile Ekonomik Katma Değeri Arasındaki Nedensellik ilişkisi: Panel Nedensellik Analizi", BDDK Bankacilık ve Finansal Piyasalar Dergisi, 14, (1), 2020, 39-67 
Tablo 6: IPS Panel Birim Kök Testi

\begin{tabular}{|lccc|}
\hline Değişken & Olasılık Değeri & Sonuç & Durağanlık Derecesi \\
\hline EVA & 0,885 & Durağan Dışı & 1. Derece \\
\hline PD & 0,762 & Durağan Dışı & 1. Derece \\
\hline
\end{tabular}

Tablo 6'da yer alan IPS panel birim kök test sonuçlarına bakıldığında değişkenlerin birinci farkında durağan olduğu görülmektedir. Bu çerçevede EVA ve PD serileri için durağanlığın sağlanamadığı görülmektedir. Bu nedenle sözkonusu serilerin birinci derece farkı alınarak durağan hale gelmesi sağlanmıştır.

Seriler farkı alınarak durağan hale getirildikten sonra, seriler arasında uzun dönemli ilişkilerin varlığı eşbütünleşme testleri ile belirlenir. Birinci farkında durağan hale gelen EVA ile piyasa değeri verileri arasındaki uzun dönemli ilişkiler Westerlund (2008) Durbin-Hausman yöntemi ile belirlenmeye çalışılmıştır. Tezin hipotezleri şu şekildedir:

$H_{0}$ : Eşbütünleşme ilişkisi yok.

$H_{1}$ : Eşbütünleşme ilişkisi var.

Hipotezlerin red veya kabulüne, elde edilen test istatistiğinin normal dağılım tablosu kritik değerleriyle karşılaştırılmasıyla karar verilmektedir. Buna göre, elde edilen test istatistiği \%5 anlamlılık düzeyinde 1.645'ten büyük olduğunda, HO reddedilmekte ve eşbütünleşme ilişkisinin varlığına karar verilmektedir.

Westerlund (2008) Durbin-Hausman yönteminde, eşbütünleşme ilişkisinin varlığı, grup ve panel boyutunda ayrı ayrı test edilmektedir. Westerlund (2008) Durbin-Hausman grup testinde otoregresif parametrenin kesitler arasında farklılaşmasına izin verilmektedir. Bu testte $\mathrm{H}_{0}$ hipotezinin reddedilmesi, en azından bazı kesitler için eşbütünleşme ilişkisinin varlığını ifade etmektedir. Westerlund (2008) Durbin-Hausman panel eşbütünleşme testinde ise, otoregresif parametrenin bütün kesitler için aynı olduğu kabul edilmektedir. Bu varsayım altında, $\mathrm{H}_{0}$ hipotezi reddedildiğinde, bütün kesitler için eşbütünleşme ilişkisinin var olduğu kabul edilmektedir (Bayar, Güloğlu v.d., 2011). Buna göre Tablo 7'deki test sonuçları elde edilmiştir. 
Tablo 7: Durbin-H Panel Eşbütünleşme Testi

\begin{tabular}{|l|c|c|c|l|}
\hline & İstatistik Değeri & Olasılık Değeri & Kritik Değer (\%5) & Karar \\
\hline $\begin{array}{l}\text { Durbin-H Grup } \\
\text { İstatistiği }\end{array}$ & 1.826 & 0.0000 & 1.645 & $\begin{array}{l}\text { Eşbütünleşme } \\
\text { iliş̧kisi vardır. }\end{array}$ \\
\hline $\begin{array}{l}\text { Durbin-H Panel } \\
\text { İstatistiği }\end{array}$ & 1.683 & 0.0002 & 1.645 & $\begin{array}{l}\text { Eşbütünleşme } \\
\text { ilişkisi vardır. }\end{array}$ \\
\hline
\end{tabular}

Test sonucunda elde edilen grup ve panel istatistiklerinin 1.645'ten büyük olduğu görülmektedir. Bu durumda $\mathrm{H}_{0}$ hipotezi red edilmiş ve banka gruplarında ve panelin genelinde, değişkenlere ilişkin seriler arasında eşbütünleşme ilişkisinin olduğu sonucuna ulaşılmıştır. Dolayısıyla bu çalışmada yapılan panel veri eşbütünleşme testi sonuçlarında çalışma kapsamındaki bankaların EVA'ları ile piyasa değerleri arasında uzun dönemli ve istatistiki açıdan eşbütünleşik ilişki tespit edilmiştir.

Çalışmada seriler arasındaki nedensellik ilişkisi Dumitrescu ve Hurlin (2012) tarafından geliştirilen panel nedensellik testiyle araştırılmıştır. Dumitrescu ve Hurlin (2012) tarafından geliştirilen bu test, zaman boyutu ile kesit boyutu arasındaki büyüklük farkına karşı duyarsız olup, zaman boyutu kesit boyutundan büyük veya küçük olduğunda test, etkin sonuçlar üretebilmektedir (Bozoklu ve Yılancı, 2013). Dumitrescu ve Hurlin (2012) yönteminde aşağıdaki hipotezler sınanmaktadır:

$\mathrm{H}_{0}$ : Tüm birimler için y değişkeni, $\mathrm{x}$ değiş̧keninin nedenseli değildir.

$\mathrm{H}_{1}$ : Bazı birimler için y değişkeni, $\mathrm{x}$ değişkeninin nedenselidir.

Tablo 8: Dumitrescu-Hurlin Granger Nedensellik Testi

\begin{tabular}{|l|l|l|l|l|}
\hline Nedenselliğin Yönü & W İstatistiği & Z İstatistiği & Olasılık & Karar \\
\hline EVA $\rightarrow$ PD & 4,86844 & 3,46210 & 0,0000 & Nedensellik Var \\
\hline PD $\rightarrow$ EVA & 2,26814 & 0,00473 & 0,9627 & Nedensellik Yok \\
\hline
\end{tabular}

Değişkenler arasında nedensellik ilişkilerini inceleyen Dumitrescu ve Hurlin Panel nedensellik test sonuçları Tablo 8'de verilmiştir. Çalışmada, EVA'dan piyasa değerine doğru nedensellik ilişkisinin olduğu görülmüştür. Bu ilişki, çalışmaya konu olan bankalarda ilgili dönemde gerçekleşen EVA'nın piyasa değerini etkilediğini ifade etmektedir. Buna karşılık piyasa değerinden EVA'ya doğru bir nedensellik ilişkisi tespit edilememiştir.

T. Figankaplan, "Bankaların Piyasa Değeri ile Ekonomik Katma Değeri Arasındaki Nedensellik Illişkisi: Panel Nedensellik Analizi”, BDDK Bankacilık ve Finansal Piyasalar Dergisi, 14, (1), 2020, 39-67 


\section{Sonuç}

Bu çalışmada, hisseleri borsada işlem gören 7 mevduat bankasının 2004-2018 yıllarına ait çeyrek dönem verileri kullanılarak, ekonomik katma değerleri ve piyasa değerleri arasındaki ilişki panel eşbütünleşme ve nedensellik analizi ile incelenmiştir. Analiz sonucunda, çalışma kapsamındaki bankaların ekonomik katma değerleri ile piyasa değerleri arasında uzun dönemli ve istatistiki açıdan eşbütünleşik ilişki olduğu görülmüştür. Ayrıca sözkonusu bankaların ekonomik katma değerinden piyasa değerine doğru nedensellik ilişkisinin olduğu tespit edilmiştir. Bu ilişki, çalışmaya konu olan bankalarda ilgili dönemde gerçekleşen ekonomik katma değerin piyasa değerini etkilediğini ifade etmektedir. Bu sonuç, banka stratejilerinin ekonomik katma değer üretimine ve ekonomik katma değerin arttırılmasına yönelik planlanması ve uygulanmasının bankanın piyasa değerinin de artmasına yol açacağını ifade etmektedir. Ayrıca bu sonuç, literatür çalışmalarında EVA'daki iyileşmenin bankaların piyasa değerini artıracağı yönündeki bulgularla örtüşmektedir. Buna karşıllık çalışma sonucunda, piyasa değerinden ekonomik katma değere doğru bir nedensellik ilişkisi tespit edilememiştir.

Günümüzde yatırımcıların isabetli yatırım kararları verebilmeleri, yatırım araçlarının gerçek değerine dair doğru bilgiye sahip olmalarıyla mümkün olabilir. Özellikle ülkemizde firmaların halka arzının teşvik edildiği ve sermaye piyasalarının gelişmesi için çaba sarf edildiği dikkate alındığında, bunun önemi daha net anlaşımaktadır. Aynı şekilde firmaların piyasa değerini en yüksek düzeye çıkarması, finansal performanslarını doğru ölçmeleri ve değerlendirmeleri suretiyle sağlanabilir. Bu açıdan doğru ve isabetli performans ölçümü hem bankalar hem de hissedarları başta olmak üzere tüm paydaşları açısından önemlidir.

Diğer taraftan bankaların faaliyetlerini sürdürebilmeleri için değer yaratmaları büyük önem taşımaktadır. Bankalarda faaliyet sonucunda yaratılan değerin ölçülmesinde ve yönetim etkinliğinin sağlanmasında kullanılan finansal bir araç olan EVA, bir yandan finansal performansı ölçerken bir yandan da değere dayalı yönetim anlayışının en önemli araçlarından birisi olmaktadır. EVA, bankanın faaliyetlerinde kullandığı kaynakların maliyetleri ile bankanın ya da bankanın iş birimlerinin yarattığı değeri hissedarlar ve diğer menfaat grupları için görünebilir bir hale getirmektedir. Bu anlamda EVA bankalarda "organizasyonel başarı" kavramına yeni bir tanım getirecek mahiyettedir. Hem banka yöneticileri, çalışanları, hissedarları ve diğer tüm paydaşların hem de bankanın lehine olacak değerlendirme kriteri niteliğinde bir ölçüttür.

EVA'nın geleneksel performans ölçütlerinden farkı, bankaların finansal perfor- 
mansını muhasebe bilgilerine ek olarak muhasebe dışı verilerden de yararlanarak sunmasıdır. EVA, bankanın katma değer yaratma performansının bir göstergesi olduğundan ve değer yaratan faaliyetlerinin belirlenmesini sağladığından, bankanın yönetim kararlarının ve plasman politikalarının oluşturulmasında yol gösterici niteliktedir. EVA yöntemini uygulayan bankalar maliyetlerini işlem, ürün, hizmet ve müşteri segmenti bazında belirleyebilir ve bu suretle maliyet yönetimini daha etkin yapabilirler. EVA yöntemi, kurumsal, bireysel, KOBi bankacılığı ya da hazine işlemleri gibi faaliyet türleri itibariyle tahsis edilen özsermayenin ne ölçüde değer yarattığını hesaplamayı mümkün kılmaktadır. Dolayısıyla EVA, bankanın performansının hem bir bütün olarak hem de faaliyet türü ya da işlem, ürün, müşteri türü bazlı olarak takip edilmesini sağlamaktadır.

EVA'nın bir performans göstergesi olarak kullanılmasının en önemli etkisi, bankanın özsermaye maliyetinin önemini vurgulamasından dolayı, banka yönetimlerini banka hissedarı gibi düşünmeye ve bunu gözeten politikalar uygulamaya yönlendirecek olmasıdır. Ayrıca hissedar değerindeki değişimin de anlamlı bir göstergesi olduğundan, yatırımcılara ve paydaşlara bankanın hisse değeri hakkında daha anlamlı bilgiler sunmaktadır.

Son yıllarda kullanımı ve önemi giderek artan EVA gibi değere dayalı yönetim anlayışı ve bu anlayış paralelinde geliştirilen finansal performans ölçüm yöntemlerinin, yatııım kararlarının değerlendirilmesinde, bankaların finansal performansının ölçülmesinde hem yatırımcılara hem de yöneticilere önemli katkılar sağlayabileceği düşünülmektedir.

Bu çalışmanın sonuçlarını değerlendirirken göz önünde bulundurulması gereken diğer husus, çalışma kapsamında EVA'nın sadece piyasa değeri ile nedensellik ilişkisinin incelendiğidir. Dolaysıyla çalışma sonuçları, çalışma kapsamında olmayan diğer performans göstergeleri açısından aynı sonucun çıkacağı anlamına gelmemektedir. Daha fazla sayıda gösterge ile farklı değişkenler kullanılarak yapılacak analizlerde farklı sonuçlara ulaşılabilir. Konuya ilişkin olarak yapılacak sonraki çalışmalarda farklı sektörlerden daha fazla firmanın kapsama alınması ve yıl sayısının artırıması, EVA'nın bir performans göstergesi olarak açıklama gücünün daha iyi anlaşımasını sağlayacaktır.

T. Figankaplan, "Bankaların Piyasa Değeri ile Ekonomik Katma Değeri Arasındaki Nedensellik ilişkisi: Panel Nedensellik Analizi", BDDK Bankacilık ve Finansal Piyasalar Dergisi, 14, (1), 2020, 39-67 


\section{Kaynakça}

1. Aggarwal, R.. (2001). Using Economic Profit to Assess Performance: A Metric for Modem Firms. Business Horizons, January-February.

2. Akgül, B.A.. (2004). İşletmelerde Yeni Performans Ölçümleme Sistemleri. Muhasebe ve Finansman Dergisi, Ekim, 24: 73-82.

3. Al-Awawdeh, H.A. ve Al-Sakini, S.A.K.. (2018). The Impact of Economic Value Added, Market Value Added and Traditional Accounting Measures on Shareholders' Value: Evidence from Jordanian Commercial Banks. International Journal of Economics and Finance, 10(10): 40-51.

4. Armitage, H.. (1997). "Measuring and Managing Shareholder Value Creation", CMA Management Accounting Guideline 44, 12(3): 1-51.

5. Bayar, G., Güloğlu, B. ve Tokpunar, S.. (2011). Ekonomik Yaklaşım Kongresi: Türkiye Ekonomisinin Dinamikleri: Politika Arayışları, 22-23 Aralık.

6. Bhasin, M. L. ve Shaikh, J. M.. (2013). Economic Value Added and Shareholders' Wealth Creation : The Portrait of a Developing Asian Country. International Journal of Managerial and Financial Accounting, 5(2): 107-137.

7. Breusch, T. ve Pagan, A. R.. (1980). The Lagrange Multiplier Test and Its Applications to Modelspecification Tests in Econometrics. Review of Economic Studies, 47: 239-53.

8. Brewer, C. P., Chandra, G. ve Clayton, A. H.. (1999). Economic Value Added (EVA): Its Uses and Limitations. Sam Advanced Management Journal, Spring.

9. Brooks, C.. (2008). Introductory Econometrics for Finance $\left(2^{\text {th }}\right.$ Ed.). UK, Cambridge University Press.

10. Bognarova, K.J.. (2017). Analysis of the Relationship Between Economic Value Added and Market Value Added. Challenges of the Knowledge Society, Finance and Accounting, 5(13): 793-796.

11. Bozoklu, Ş. ve Yılancı, V.. (2013). Finansal Gelişme ve iktisadi Büyüme Arasındaki Nedensellik ilişkisi: Gelişmekte Olan Ekonomiler İ̧̧in Analiz. Dokuz Eylül Üniversitesi Iktisadi ve İdari Bilimler Fakültesi Dergisi, 28(2): 161-187. 
12. Ceylan, A. ve Korkmaz, T.. (2008). İşletmelerde Finansal Yönetim. Bursa: Ekin Kitabevi Yayınları.

13. Çakıcı, C.. (2008). Ekonomik Katma Değer EVA Yaklaşımı. İstanbul: Beta Basım Yayın.

14. Çelik, O.. (2002). İşletmelerde Bir Performans Ölçütü Olarak Ekonomik Katma Değer ve Türk Telekom AŞ de Bir Uygulama. MÖDAV Dergisi, 4(1).

15. Çetin, A. (2019). Yaşayan ve Gelişen Katılım Bankacılığı. (Ed.) Şakir Görmüş, Ahmet Albayrak, Aydın Yabanlı. İstanbul: TKBB Yayınları.

16. Drucker, P. F.. (1995). The Information Executives Truly Need. Harvard Business Review, 59.

17. Fayed, A.M. ve Dubey, S.. (2016). An Empirical Study of Impact of EVA Momentum on the Shareholders' Value Creation as Compared to Traditional Financial Performance Measures-With Special Reference to the UAE. International Journal of Economics and Finance, 8(5): 23-38.

18. Gökbulut, R.İ.. (2009). Hissedar Değeri İle Finansal Performans Ölçütleri Arasındaki İlişki Ve IMKB Üzerine Bir Araştırma, Doktora Tezi. İstanbul Üniversitesi Sosyal Bilimler Enstitüsü, İstanbul.

19. Kijewska, A.. (2016). Causal Analysis of Determinants Influencing the Economic Value Added (EVA) - A Case of Polish Entity. Journal of Economics and Management, 26(4): 52-70.

20. Kim, W. G.. (2006). EVA and Traditional Accounting Measures: Which Metric is a Better Predictor of Market Value of Hospitality Companies. Journal of Hospitality and Tourism Research, 30(1): 34-49.

21. Kootanaee, H. J., Kootanaee, A. J., Talari, H. F. ve Babu, K. N.. (2012). A Comparison of Performance Measures for Finding the Best Measure of Business Entity Performance: Source from the Tehran Stock Exchange. Journal of Finance and Investment Analysis, 1(4): 27-35.

22. Köroğlu, A.. (2008). Bankaların Tasfiyesinde Ekonomik Katma Değerin Hesaplanması ve Türk Bankacılık Sektöründe Uygulanması, Doktora Tezi, Gazi Üniversitesi Sosyal Bilimler Enstitüsü, Ankara. 
23. Kyriazis, D. ve Anastassis, C.. (2007). The Validity of the Economic Value Added Approach: An Empirical Application. European Financial Management, 13(1): 71-100.

24. O'Byrne, S. F.. (1996). EVA and Market Value. Journal of Applied Corporate Finance, 9(1): 116-125.

25. Oboidot, A.N.. (2019). Is Economic Value Added Superior to Earnings and Cash Flows in Explaining Market Value Added? An Empirical Study. International Journal of Business, Accounting and Finance, 13(1): 57-69.

26. Panigrahi, S.K.. (2017). Economic Value Added and Traditional Accounting Measures for Shareholder's Wealth Creation. Asian Journal of Accounting and Governance, 8: 125-136.

27. Panigrahi, S.K., Zainuddin, Y. ve Azizan, A.. (2014). Comparing Traditional and Economic Performance Measures for Creating Shareholders' Value: A Perspective From Malaysia. International Journal of Academic Research in Accounting, Finance and Management Science, 4(4): 280-289.

28. Pesaran, M. H.. (2004). General Diagnostic Tests for Cross Section Dependence in Panels. Cambridge Working Papers in Economics, 435.

29. Pesaran, M. H., ve Yamagata, T.. (2008). Testing Slope Homogeneity in Large Panels. Journal of Econometrics, 142(1), 50-93.

30. Prakash, A. J., Chang, C., Davidson, L., ve Lee, C.. (2003). Adoption of Economic Value Added and Financial Ratios. The International Journal of Finance, 15(2): 2574-2592.

31. Shil, N.. (2009). Performance Measures: An Application of Economic Value Added. International Journal of Business and Management, 4(3): 169-177.

32. Sipahi, B., Yanık, S. ve Aytürk, Y. (2011). Şirket Değerleme Yaklaşımları. İstanbul: Nobel Yayıncılık.

33. Strack, R. ve Ulrich, V.. (2002). RAVE: Integrated Value Management for Customer, Human, Supplier and Invested Capital. European Management Journal, 20(2): 147-158. 
34. Türker, I... (2005). Ekonomik Katma Değer EVA'nın Hesaplanması ve Gerekli Muhasebe Düzeltmeleri. Muhasebe ve Denetime Bakış Dergisi, No:15: 147.

35. Wadi, R.A. ve Saqfalhait, N.. (2016). Economic Value Added as a Complementary Tool to Evaluate the Performance of the Jordanian Commercial Banks. An-Najah University Journal for Research: Humanities, 8(12):21-36.

36. Westerlund, J., (2008). A Panel Cointegration Tests of the Fisher Effects, Journal of Applied Econometrics, 23, s.193-233.

37. Worthington, A. C. ve West, T.. (2004). Australian Evidence Concerning the Information Content of Economic Value Added. Australian Journal of Management, 29(2): 201-224.

38. Vijayakumar, A.. (2011). Economic Value Added (EVA) and Shareholders Wealth Creation: A Factor Analytic Approach. Research Journal of Finance and Accounting, 2(12): 22-37. 